\title{
RISK OF HYPERKALEMIA ASSOCIATED WITH THE USE OF BLOCKERS OF THE RENIN-ANGIOTENSIN-ALDOSTERONE SYSTEM IN THE TREATMENT OF HEART FAILURE: A REVIEW
}

\author{
Gabriela da Silveira Aguiar Undergraduate medical student of Bahiana \\ School of Medicine and Public Health (BAHIA- \\ NA), Salvador, BA, Brazil. \\ Zilma Régia de Sousa Barreto Undergraduate medical student of Bahiana \\ School of Medicine and Public Health (BAHIA- \\ NA), Salvador, BA, Brazil. \\ Constança Margarida Sampaio Cruz Leader of Multidisciplinary Research Group of \\ Hospital Santo Antonio, BA, Brazil. Residency \\ Program of Clinical Medicine, Hospital Santo \\ Antonio. Salvador, Bahia, Brazil. Adjunt Pro- \\ fessor Bahiana School of Medicine and Public \\ Health, Salvador, BA, Brazil.
}

\section{Corresponding author}

Constança Margarida Sampaio Cruz

E-mail: conscruz@terra.com.br

\begin{abstract}
Heart failure (HF) is the leading cause of hospitalizations for cardiovascular diseases in Brazil. Hyperkalemia is an important adverse effect of therapy for HF. Several factors affect the incidence of hyperkalemia in patients treated for HF, as well as the presence of comorbidities and the use of associated medications. The aim of this study is to gather new evidence regarding the risk of hyperkalemia in patients treated for HF. The well-established therapy for HF involves drugs that may lead to hyperkalemia as inhibitors of angiotensin converting enzyme blockers, angiotensin II receptor blockers, aldosterone receptor blockers and direct renin inhibitors. The high incidence of HF in elderly patients with comorbidities such as diabetes mellitus and renal insufficiency increases the risk of hyperkalemia. Anti-inflammatory drugs, trimethoprim-sulfamethoxazole and heparin may aggravate the situation. Conclusion: Given the risk of hyperkalemia in patients undergoing treatment for HF, cautious monitoring of renal function and serum potassium should be performed.
\end{abstract}

Keywords: Hyperkalemia; Heart failure; Blockers of the renin-angiotensin-aldosterone system. 


\section{INTRODUCTION}

The treatment of heart failure (HF) involves the use of blockers of the renin-angiotensin-aldosterone system (RAAS) ${ }^{(1-5)}$ Aging, diabetes mellitus (DM), renal insufficiency and associated use of anti-inflammatory drugs (NSAIDs), heparin, and trimethoprim-sulfamethoxazole can induce hiperkalemia in heart failure patients treated with RAAS blockers. ${ }^{(6,7)}$ The aim of this study is to gather new evidence regarding the risk of hyperkalemia in HF patients.

\section{METHODS}

This review article searched for original articles and guidelines in English on MEDLINE from 1998 to 2012 using the following keywords: hyperkalemia, heart failure, angiotensin-converting enzyme inhibitors, angiotensin receptor blockers, aldosterone antagonists and direct inhibitor renin.

\section{RESULTS}

ACE inhibitors increase survival rates in patients with $\mathrm{HF}^{(8-11)}$ These drugs reduce systemic vascular resistance without increasing heart rate, decreasing rates of re-infarction and unstable angina, and improving the quality of life. ${ }^{(12-15)}$

According to the AHA Scientific Statement, Acute kidney injury (AKI) related to treatment with ACE inhibitors usually occurs at the beginning of therapy. This document recommends that the use of ACE inhibitors should be discontinued if there is a sustained increase greater than $50 \%$ in serum creatinine baseline or in case of hyperkalemia with serum potassium greater than $5.5 \mathrm{mEq} / \mathrm{L} .{ }^{(16-18)}$

Angiotensin receptor blockers (ARBs)

The blockade of angiotensin II receptors may represent an important therapeutic strategy because it promotes more complete blockade of the RAAS, maintaining beneficial effects mediated by stimulation of AT2 receptors. ${ }^{(19-24)}$

The ELITE I study evaluated 722 patients randomized to receive treatment with captopril (50 mg) three times daily or losartan $(50 \mathrm{mg}$ ) once daily, for 48 weeks, showing lower mortality in the group that used losartan. On the other hand, the ELITE II study evaluated 3132 patients and showed no difference between the groups treated with losartan or captopril related to mortality. There was a lower incidence of cough in the losartan group, whereas no difference was found between these drugs regarding the rates of AKI and hipercalemia. ${ }^{(25,26)}$ 


\section{Aldosterone blockers}

Spironolactone

Aldosterone is associated with an increase of fibroblast proliferation and perivascular fibrosis. Its blockade reduces collagen synthesis, improves cardiac function and prevents remodeling. ${ }^{(27-31)}$ The RALES study showed a 30\% reduction in mortality in the group treated with 25 - $50 \mathrm{mg}$ of spironolactone as compared with placebo. ${ }^{(4)}$ After its publication, several clinical studies have demonstrated the occurrence of hyperkalemia associated to the combination of ACE inhibitors and spironolactone for treating heart failure and serious clinical disorders were related to the increase in plasma levels of this electrolyte, including death. ${ }^{(31-40)}$

\section{Eplerenone}

Eplerenone is the first of a new class of drugs known as a selective blocker aldosterone receptor. It has minimal effect on steroid receptor, thereby minimizing the hormonal effects observed with spironolactone, such as ginecomastia. ${ }^{(41-44)}$

The EPHESUS study demonstrated a significant reduction in cardiovascular mortality and sudden death rates associated with the use of eplerenone. There was significant increase in the occurrence of severe hyperkalemia and decreased incidence of hypokalemia in the group treated with this drug. ${ }^{(45)}$

\section{Betablockers}

Beta blockers also favor the increase in serum potassium levels through two distinct mechanisms: blocking the stimulating action of the sympathetic nervous system on renin release and inhibition of the sodium-potassium ATPase, thus reducing cellular uptake of potassium. ${ }^{(8,18)}$

\section{Renin inhibitors}

The study "Effects of the Oral Direct Renin Inhibitor Aliskiren in Patients With Symptomatic Heart Failure", conducted in 2008, concluded that aliskiren (150 mg / day) associated with the standard therapy of heart failure with ACE inhibitors (or ARBs) and beta-blockers appeared to be well tolerated and showed favorable neurohumoral effects, however there was no change in NYHA functional class of Heart Failure (HF), requiring new randomized controlled trials to prove the clinical efficacy and safety in $\mathrm{HF}^{(46-48)}$ 
Predictors of hyperkalemia in HF patients

Chronic Renal Disease

Although demonstrate effective use of ACE inhibitors in patients with HF and chronic renal disease light to moderate, the CONSENSUS study showed no safety in patients with renal failure in advanced stages. ${ }^{(9)}$

The association of spironolactone with ACE inhibitors or ARBs should be avoided in patients in advanced stages of Chronic Renal Disease..$^{(4,39.40)}$

Advanced age

Important changes in the kidney have been described associated with aging, such as the progressive loss of nephrons, decreased glomerular filtration rate and reduced secretion of renin and aldosterone. ${ }^{(49-51)}$

Diabetes mellitus (DM)

Diabetic patients are more likely to develop hyperkalemia due to a decrease in insulin production, limiting the movement of intracellular potassium from the extracellular fluid. ${ }^{40,52}$

Hyporeninemic hypoaldosteronism is associated with diabetes, decreasing sodium reabsorption and potassium excretion. ${ }^{(52)}$

Ahuja ${ }^{(53)}$ retrospectively studied 119 patients using ACE inhibitors and found that $38.6 \%$ developed hyperkalemia. Of these, $96 \%$ had chronic renal disease and $84 \%$ were diabetic.

The association of DM and hyperkalemia has been described by other authors ${ }^{(54-55)}$ with one case of a patient who developed severe hyperkalemia ( $8.9 \mathrm{mmol} /$ L) 18 days after the beginning of the therapy with spironolactone and ACE inhibitors, with subsequent normalization of serum potassium after suspending drugs.

Vomiting and diarrhea

Schepkens et al. reported a serie of 25 patients with episodes of life-threatening hyperkalemia in patients treated with association of spironolactone and ACE inhibitors. Twelve of these patients showed signs of volume depletion associated with vomiting, diarrhea, infection and fever. ${ }^{(32)}$

Advanced heart failure

Svensson and col. ${ }^{(34)}$ found that low ejection fraction of the left ventricle and advanced stages of heart failure were independent predictors of hiperkalemia. 
Drugs related to hyperkalemia

Anti-inflammatory drugs (NSAIDs)

When in combination with ACEI, an exacerbation of hypoaldosteronism can occur, increasing the risk of hyperkalemia in these patients. This risk is also present with the combination of selective COX-2 and ACE inhibitors, so these drugs should be avoided in these patients. ${ }^{(18)}$

\section{Heparin}

Heparin causes hypoaldosteronism through a blocking of the synthesis of aldosterone by the adrenal increasing the risk of hypercalemia in patients using this drug, especially when associated with therapy for the treatment of IC. ${ }^{(18)}$

Sulfamethoxazole and trimethoprim (SMX-TMP)

A case-control study carried out in Ontario evaluated the risk of hyperkalemia in chronic users of spironolactone who had treated an urinary infection with TPMSMX or nitrofurantoin or norfloxacin or amoxicillin. 165.754 patients with hyperkalemia on admission or during the course of hospitalization were analysed. The authors found a strong association between the use of TMP-SMX with the occurrence of hyperkalemia in these patients. ${ }^{(56)}$

The Table 1. shows the major publications that have identified risk factors associated with hyperkalemia.

Table 1 - RISK FACTORS ASSOCLATED WITH THE DEVELOPMENT OF HYPERKALEMIA

\begin{tabular}{|c|c|c|c|c|}
\hline Reference & Publication & $\mathrm{N}$ & Predictors of hyperkalemia & $\begin{array}{l}\text { Hyperkalemia } \\
(\%)\end{array}$ \\
\hline RALES $^{4}$ & 1999 & 1663 & $\begin{array}{l}\text { Age, NYHA Heart Failure Class } \\
\text { III-IV, drugs }\end{array}$ & $1,4 \%$ \\
\hline $\begin{array}{l}\text { Schepkens \& } \\
\text { Vanholder }^{32}\end{array}$ & 2001 & 262 & $\begin{array}{l}\text { Age, Renal Disfunction, } \mathrm{DM}^{*} \text { and } \\
\text { NHAIS }^{4}\end{array}$ & $9,5 \%$ \\
\hline $\begin{array}{l}\text { Berry \& } \\
\text { McMurray }^{33}\end{array}$ & 2001 & 4 & Diarrhea and pre-renal azotemia & $100 \%$ \\
\hline $\begin{array}{l}\text { Svensson \& } \\
\text { Gustafsson }^{34}\end{array}$ & 2003 & 108 & $\begin{array}{l}\text { Age, Renal Disfunction and } \\
\text { Low ejection fraction of the left } \\
\text { ventricle }\end{array}$ & $12 \%$ \\
\hline $\begin{array}{l}\text { Wrenger \& } \\
\text { Müller }^{37}\end{array}$ & 2003 & 44 & Age, Renal Disfunction and $\mathrm{DM}^{\star}$ & $100 \%$ \\
\hline $\begin{array}{l}\text { Bozkurt \& } \\
\text { Ildiko }\end{array}$ & 2003 & 104 & Renal Disfunction and $\mathrm{DM}^{*}$ & $11,5 \%$ \\
\hline $\begin{array}{l}\text { Cruz \& Marcílio } \\
\text { de Souza }{ }^{36}\end{array}$ & 2003 & 49 & $\begin{array}{l}\text { Renal Disfunction, } \mathrm{DM}^{*} \text { and } \\
\text { NYHA Heart Failure Class IV }\end{array}$ & $14,2 \%$ \\
\hline
\end{tabular}




\begin{tabular}{|c|c|c|c|c|}
\hline $\begin{array}{l}\text { McMurray \& } \\
\text { Pitt }^{48}\end{array}$ & 2008 & 302 & $\begin{array}{l}\text { HAS }^{x}, \text { NYHA Heart failure Class } \\
\text { II-IV, }{ }^{* B N P} \text {, aliskiren }\end{array}$ & $5,6 \%$ \\
\hline $\begin{array}{l}\text { Henz \& Maed- } \\
\mathrm{er}^{57}\end{array}$ & 2008 & 10.320 & $\begin{array}{l}\text { Age, Renal disfunction, } \mathrm{DM}^{*} \text { and } \\
\text { drugs }\end{array}$ & $5 \%$ \\
\hline $\begin{array}{l}\text { Antoniou \& } \\
\text { Gomes }^{56}\end{array}$ & 2011 & 165.754 & $\begin{array}{l}\text { Age, spironolactone and }{ }^{\circledR} \mathrm{SMT} \text { - } \\
\mathrm{TMP}^{4}\end{array}$ & $10,8 \%$ \\
\hline
\end{tabular}

* Diabetes Mellitus; ${ }^{x}$ Systemic Arterial Hypertension;

${ }^{\sharp}$ Brain natriuretic peptide; ${ }^{\lessgtr}$ Trimethoprim-sulfamethoxazole.

\section{Prevention of Hyperkalemia}

Spironolactone or its combination with ACE inhibitors or ARBs are not recommended in patients with potassium $>5.0 \mathrm{mmol} / \mathrm{L}$ or creatinine clearance $<60 \mathrm{~mL} /$ $\min .^{(39,40,57,58)}$

Introducing $\mathrm{ACE}$ inhibitor at low doses and monitoring serum creatinine and potassium in the first 15 days is recommended. ${ }^{(32-37)}$ In case of good tolerance to ACE inhibitors or ARBs, spironolactone therapy must be added in a dose up to $25 \mathrm{mg} /$ day. $(16,39,40)$ The monitoring of renal function and serum potassium should be performed after the introduction of new drugs, dose changes and in case of clinical conditions that decrease renal perfusion, such as diarrhea, vomiting or worsening of heart failure..$^{(32,33)}$

\section{CONCLUSION}

Close monitoring of renal function and serum potassium should be performed in patients at the beginning and during the treatment of heart failure.

Further studies should be encouraged using a sample more similar to the "real world" for better establishment of safety associations regarding to the use of RAAS inhibitors to treat heart failure.

\section{REFERENCES}

1. BocchI EA, Braga FGM, Ferreira SMA, et al. III Diretriz Brasileira de Insuficiência Cardíaca Crônica. Arq Bras Cardiol. 2009;93(1 Suppl 1).

2. Bocchi EA, Marcondes-Braga FG, Bacal F, et al . Atualização da diretriz brasileira de insuficiência cardíaca crônica - 2012. Arq Bras Cardiol. 2012;98(1 Suppl 1).

3. Juurlink DN, Mamdani MM, Lee DS, et al. Rates of hyperkalemia after publication of the Randomized Aldactone Evaluation Study. N Engl J Med. 2004;351(6):543-51.

4. Pitt B, Zannad F, Remme WJ, et al. The Effect of spironolactone on morbidity and mortality in patients with severe heart failure. Randomized Aldactone Evaluation Study Investigators. N Engl J Med. 1999;341(10):709-17. 
5. Hunt SA, Abraham WT, Chin MH, et al. 2009 Focused update incorporated into the ACC/AHA 2005 guidelines for the diagnosis and management of heart failure in adults: a report of the American College of Cardiology Foundation/American Heart Association Task Force on Practice Guidelines developed in collaboration with the International Society for Heart and Lung Transplantation. J Am Coll Cardiol. 2009;53(15):e1-e90 [Erratum, J Am Coll Cardiol. 2009;54(25):2464.]

6. Berkova M, Berka Z, Topinkova E. (2012). Arrhythmias and ECG changes in life threatening hyperkalemia in older patients treated by potassium sparing drugs. Biomed Pap Med Fac Univ Palacky Olomouc Czech Repub. 2012;31 Epub ahead of print.

7. Sztramko R, Chau V, Wong R. Adverse drug events and associated factors in heart failure therapy among the very elderly. Can Geriatr J. 2011;14(4):79-92.

8. Cruz CS, Cruz LS, Domingues GS, et al. New strategies for treatment of heart failure with aldosterone antagonists and the risk of hyperkalemia. Expert Opin Drug Saf. 2005;4(4):677-88.

9. Effects of enalapril on mortality in severe congestive heart failure: Results of the Cooperative North Scandinavian Enalapril Survival Study (CONSENSUS). The Consensus Trial Study Group. N Engl J Med. 1987;316(23):1429-35.

10. Effect of enalapril on mortality and the development of heart failure in asymptomatic patients with reduced left ventricular ejection fractions. The Solvd Investigators N Engl J Med. 1992;327(10):685-91 [Erratum, N Engl J Med. 1992;327(24):1768].

11. Effect of enalapril on survival in patients with reduced left ventricular ejection fraction and congestive heart failure. The SOLVD Investigators. N Engl J Med. 1991;325(5):293-302.

12. Pfeffer MA, Braunwald E, Moye LA, et al. Effect of captopril on mortality and morbidity in patients with left ventricular dysfunction after myocardial infarction. Results of the survival and ventricular enlargement trial. The SAVE investigators. N Engl J Med. 1992;327(10):669-77.

13. Effect of ramipril on mortality and morbidity of survivors of acute myocardial infarction with clinical evidence of heart failure. The Acute Infarction Ramipril Efficacy (AIRE) Study Investigators. Lancet. 1993;342(8875):821-8.

14. Packer M, Poole-Wilson PA, Armstrong PW, et al. Comparative effects of low and high doses of the angiotensin-converting enzyme inhibitor, lisinopril, on morbidity and mortality in chronic heart failure. Circulation. 1999;100(23):2312-8.

15. Cohn JN, Johnson G, Ziesche S, et al. A comparison of enalapril with hydralazine-isosorbide dinitrate in the treatment of chronic congestive heart failure. N Engl J Med. 1991;325(5):303-10.

16. Ljungman S, Kjekshus J, Swedberg K. Renal function in severe congestive heart failure during treatment with enalapril (the Cooperative North Scandinavian Enalapril Survival Study [CONSENSUS] Trial). Am J Cardiol. 1992;70(4):479-87.

17. Schoolwerth AC, Sica DA, Ballermann BJ, et al. Renal considerations in angiotensin converting enzyme inhibitor therapy: a statement for healthcare professionals from de Council on de Kidney in Cardiovascular Disease and the Council for High Blood Pressure Research of the American Heart Association. Circulation. 2001;104(16):1985-91.

18. Palmer BF. Managing hyperkalemia caused by inhibitors of the renin-angiotensin-aldosterone system. N Engl J Med. 2004;351(6):585-92.

19. Batlouni M, Ramires JAF, Mello EP. Inibidores da enzima conversora de angiotensina. In: Farmacologia e terapêutica cardiovascular. São Paulo: Atheneu; 1999. p. 287-300.

20. Goodfriend TL, Elliot ME, Catt KJ. Angiotensin receptor and their antagonists. N Engl J Med. 1996;334(25):1649-54. 
21. Cohn JN, Tognoni G. A randomized trial of the angiotensin-receptor blocker valsartan in chronic heart failure. N Engl J Med. 2001;345(23):1667-75.

22. Brunner HR, Delacrétaz E, Nussberger J, et al. Angiotensin II antagonists DuP 753 and TCV 116. J Hypertens Suppl. 1994;12(9):S29-34.

23. Weber MA, Byyny RL, Pratt JH, et al. Blood pressure effects of the angiotensin II receptor blocker, losartan. Arch Intern Med. 1995;155(4):405-11. [Erratum in: Arch Intern Med. 1995;155(8):876].

24. Gradman AH, Arcuri KE, Goldberg AI, et al. A randomized, placebo-controlled, double-blind, parallel study of various doses of losartan potassium compared with enalapril maleate in patients with essential hypertension. Hypertension. 1995;25(6):1345-50.

25. Pitt B, Segal R, Martinez FA, et al. Randomised trial of losartan versus captopril in patients over 65 with heart failure (Evaluation of Losartan in the Elderly Study, ELITE). Lancet. 1997;349(9054):747-51.

26. Pitt B, Poole-Wilson PA, Segal R, et al. Effect of losartan compared with captopril on mortality in patients with symptomatic heart failure: randomized trial--the Losartan Heart Failure Survival Study ELITE II. Lancet. 2000;355(9215):1582-7.

27. Pfeffer MA, McMurray JJ, Velazquez EJ, et al. Valsartan, captopril, or both in myocardial infarction complicated by heart failure, left ventricular dysfunction, or both. The Valsartan in Acute Myocardial Infarction Trial Investigators. N Engl J Med. 2003;349(20):1893-906. [Erratum in: N Eng] J Med. 2004;8;350(2):203].

28. Giorgi DMA. Diuréticos. In: Batlouni M, Ramires JAF, (editores). Farmacologia e terapêutica cardiovascular. São Paulo: Atheneu; 1999. p. 131-2.

29. Jackson EK. Diuréticos. In: Goodman LS, Gilman AG, (editores). As bases farmacológicas da terapêutica. Chile: McGraw-Hill Interamericana; 1996. p. 517-8.

30. Zannad F. Aldosterone and heart failure. Eur Heart J. 1995;16(2):98-102.

31. Weber KT. Aldosterone and spironolactone in heart failure. N Engl J Med. 1999;341:753-5.

32. Schepkens H, Vanholder R, Billiouw JM, et al. Life-threatening hyperkalemia during combined therapy angiotensin-converting enzyme inhibitors and spironolactone: an analysis of 25 cases. Am J Med. 2001;110(6):438-41.

33. Berry C, McmurraY JJ. Serious adverse events experienced by patients with chronic heart failure taking spironolactone. Heart. 2001;85(4):E8.

34. Svensson M, Gustafsson F, Galatius S, et al. Hyperkalaemia and impaired renal function in patients taking spironolactone for congestive heart failure: retrospective study. BMJ.

2003;327(7424):1141-2.

35. Bozkurt B, Agoston I, Knowlton AA. Complications of inappropriate use of spironolactone in heart failure: when an old medicine spirals out of new guidelines. J Am Coll Cardiol. 2003;41(2):211-4.

36. Cruz CS, Cruz AA. Marcílio de Souza CA. Hyperkalemia in congestive heart failure patients using ACE inhibitors and spironolactone. Nephrol Dial Transplant. 2003;18(9):1814-9.

37. Wrenger E, Muller R, Moesenthin M, et al. Interaction of spironolactone with ACE inhibitors or angiotensin receptor blockers: analysis of 44 cases. BMJ. 2003;327(7407):147-9.

38. Tang WH, Francis GS. Spironolactone in chronic heart failure: all's well that ends well. J Am Coll Cardiol. 2003;41(2):215-6.

39. Shlipak MG. Pharmacotherapy for heart failure in patients with renal insufficiency. Ann Inter Med. 2003;138(11):917-24.

148 / Brazilian Journal of Medicine Health. 2013 Ago; 2(1):141-149 
40. Sica DA, Gehr TW, Yancy C. Hyperkalemia, congestive heart failure, and aldosterone receptor antagonism. Congest Heart Fail. 2003;9(4):224-9.

41. Brown NJ. Splerenone: cardiovascular protection. Circulation. 2003;107(19):2512-8.

42. Delyani JA. Mineralocorticoid receptor antagonists: the evolution of utility and pharmacology. Kidney Int. 2000;57(4):1408-11.

43. Moore TD, Nawarskas JJ, Anderson JR. Eplerenone: a selective aldosterone receptor antagonist for hypertension and heart failure. Heart Dis. 2003;5(5):354-63.

44. Pitt B, Roniker B. Eplerenone, a novel selective aldosterone receptor antagonist (SARA): dose finding study in patients with heart failure. J Am Coll Cardiol. 1999;33(Suppl 2):188A-189A.

45. Pitt B, Remme W, Zannad F, et al. Eplerenone, a selective aldosterone blocker, in patients with left ventricular dysfunction after myocardial infarction. N Engl J Med. 2003;348(14):1309-21.

46. Gradman AH, Schmieder RE, Lins RL, et al. Aliskiren, a novel orally effective renin inhibitor, provides dose-dependent antihypertensive efficacy and placebo-like tolerability in hypertensive patients. Circulation. 2005;111(8):1012-8.

47. Harel Z, Gilbert C, Wald R, et al. The effect of combination treatment with aliskiren and blockers of the renin-angiotensin system on hyperkalaemia and acute kidney injury: systematic review and meta-analysis. BMJ. 2012;344:e42.

48. Mcmurray JJ, PITT, B, Latini R, et al. Effects of the oral direct renin inhibitor aliskiren in patients with symptomatic heart failure. Circ Heart Fail. 2008;1(1):17-24.

49. Perazella MA. Hyperkalemia in the elderly: a group at high risk. Conn Med. 1996;60(4):195-8.

50. MacDowall P, Kalra PA, O’Donoghue DJ, et al. Risk of morbidity from renovascular disease in elderly patients with congestive cardiac failure. Lancet. 1998;352(9121):13-6.

51. Jessup M, Brozena S. Heart failure. N Engl J Med. 2003;348(20):2007-18.

52. Defronzo RA. Hyperkalemia and hyporeninemic hypoaldosteronism. Kidney Int. 1980;17(1):118-34.

53. Ahuja TS, Freeman D JR. Mahnken JD, et al. Predictors of the development of hyperkalemia in patients using angiotensin-converting enzyme inhibitors. Am J Nephrol. 2000;20(4):268-72.

54. Albareda MM, Corcoy R. Reversible impairment of renal function associated with enalapril in a diabetic patient. CMAJ. 1998;159(10):1279-81.

55. Odawara M, Asano N, Yamashita K. Life-threatening hyperkalaemia caused by angiotensinconverting enzyme-inhibitor and diuretics. Diabetic Med. 1997;14(2):169-70.

56. Antoniou T, Gomes T, Mamdani MM, et al. Trimethoprim-sulfamethoxazole induced hyperkalaemia in elderly patients receiving spironolactone: nested case-control study. BMJ. 2011;343:d5228.

57. Henz S, Maeder MT, Huber S, et al. Influence of drugs and comorbidity on serum potassium in 15 000 consecutive hospital admissions. Nephrol Dial Transplant. 2008;23(12):3939-45. 